\title{
The Innovation of New Talent Training Mode of School-enterprise Cooperation
}

\author{
Junmei Chen \\ Guangdong Institute of Science and Technology, Guangzhou, 510640, China \\ cjmaaa@126.com
}

\begin{abstract}
School-enterprise cooperation is a very important mode of talent training. This paper discusses a new mode of cultivation of innovative talents, including the following: the innovation mechanism, optimize specialty, reconstruction of curriculum and teaching material system, creates the "teaching" enterprises, joint recruitment training professional teaching team, and work together to establish a comprehensive evaluation system, etc.. Practice has proved that this model can promote the mutual development, to achieve mutual benefit and win-win.

Index Terms - innovation, school-enterprise cooperation, talents' training mode
\end{abstract}

As early as in the early 20th century an attempt has been made abroad in research and exploration model for school-enterprise cooperation in personnel training.

Since the 1980s, vocational education in some developed countries, practiced a broader and deeper exploration and study, thus leading to the emergence of a series of distinctive university-enterprise cooperation system, patterns and projects, such as the German"dual system", the cooperation in education in the United States, the community colleges, the British "work-study alternate", the Australian TAFE and NA, and the Singapore's "Teaching Factory"[1]. At present, China's vocational education has been in a period of vigorous development, great concern has been shown in school-enterprise cooperation and many vocational colleges are actively exploring the reform of school-enterprise cooperation in personnel training mode and actively explore new ways in line with national conditions and the school situation ${ }^{[2]}$ giving rise to various forms of school-enterprise cooperation in personnel training mode, such as "factory in schools", "school in plants", production learning and research mode, colleges enterprises and school system, order training mode, post practice mode, learning mode, training and alternate mode, the mode of technical innovation, engineering, professional build mode, to jointly develop curriculum model ${ }^{[1]}$. Although these patterns feature cooperative form diversification, the diversification of cooperation (government, school, enterprise, etc.) the school enterprise cooperation in personnel training mode of deep connotation of the research is relatively weak, and a practical level of specific measures are not perfect, not enough to solve puzzles and problems in practice, on the whole directions to ensure high-quality applied to guarantee the quality of talent cultivation are relatively deficient.

Adapting to the requirements of the employment situation in the new era, higher vocational institutions should cultivate high quality skilled production, construction and management, serve the first line of specialist-level expertise as a fundamental task, and actively adapt to regional economic and social development needs, insist on service employment-oriented, take the combination of the path of development innovative institutional mechanisms, and vigorously promote cooperative education, cooperation educating people, cooperation employment, cooperation and development, and enhance school vitality prominent targeted personnel training, flexibility and openness, continuous improvement of social services capacity, and make great efforts to build the Chinese characteristics of modern higher vocational education, and provide a strong high-skilled human resources to support economic and social development.

The key to higher vocational education lies in the characteristics, which depends on the choice of personnel training mode, while the existing talent cultivation mode, School and Enterprise Cooperation mode, is the best option to ensure the characteristics.

Guangdong Institute of Science and Technology is the national model of higher occupation education, has always insisted on the school-enterprise cooperation, work-study combination training guidelines, careful study of school enterprise cooperation in personnel training mode of the profound connotation, over the years, bold exploration and practice of talent cultivation mode reform have been made, thus establishing the distinctive characteristics of the "New Talent Training Mode" of School-Enterprise(NTTMSE). The NTTMSE is defined by the two training team (full-time teachers and technical experts, skilled craftsmen), two training positions (school and enterprise), jointly completed professional training tasks, make full use of the school and enterprise resource, school-enterprise joint planning, setting and implementing talents training process, manifests the school and enterprises in talents cultivation process jointly playing a double role of a school enterprise cooperation in personnel training mode. The NTTMSE obtained remarkable result in this school.

\section{The new talent cultivation mode of security}

School-Enterprise cooperation is the guarantee of higher education quality and characteristics of the core element and the direction of the occupation education reform and development. Since 2006, national demonstration colleges in the exploration of school enterprise cooperation in personnel training mode has made great achievements. However, on the whole, China's higher education in the cooperation between colleges and enterprises still exist some bottlenecks in the development of school and enterprise. The underlying reason is that the school-enterprise cooperation lacks a complete system 
and mechanism. So far, all levels of government have introduced some relevant documents, but the national macroscopic policy and directive strength are still not enough, therefore, the vocational colleges to innovation and the improvement of school enterprise cooperation in personnel training mode of the system and mechanism is of great significance, strengthening the connotation construction in Higher Vocational colleges at present should be one of the most important work.

The school (main campus is located in Zhuhai) in the innovation of school enterprise cooperation in personnel training mode of institutional mechanisms has made its first step, proposing the establishment of "Zhuhai City area vocational education group", based on the Zhuhai city, and the school takes the lead and the Zhuhai Industry Association, various types of enterprises in the park and the city of Zhuhai vocational education base member colleges and intermediary agencies together to form the government and one of the "resources integration and sharing of benefits" Vocational Education Alliance body, enterprise from the school, school and teaching entity in three dimensions, the innovation and perfection of the requirements of different levels of the NTTMSE talent cultivation system of running a school, management mode and operation mechanism, such as establishing and perfecting the enterprise with the NTTMSE personnel training mode which is adapted to the school personnel management system and mechanism, make manpower resource further reasonable development and use; to establish and perfect the law of production and operation of enterprises and matched to the flexible teaching organization form and flexible plan management system; to establish and improve the operation of enterprises with culture, spirit and is adapted to high speed management and service system; to establish and improve the outcome of sharing mechanism, the school-enterprise cooperation in the results for the two The economic benefit and social benefit of ceaseless promotion play a positive role in practice; to establish and perfect the security system, establish a set of scientific and reasonable evaluation of school-enterprise cooperation incentive mechanism. All these measures will help to solve the problem of low enterprise enthusiasm, unequal and risky cooperation and weak relationship, thus ensure the healthy development of school-enterprise cooperation.

\section{The key to optimize professional talents training mode}

It is clearly demonstrated in the documents of Higher Education (2006) No.16: higher vocational institutions should keep up with quick changes in market demand, actively adapt to the needs of regions, industries, economic and social development, according to the conditions for running schools, and adjust and set new Subjects. During the"Eleventh Five-Year" period, the state will take priority in supporting those institutions with excellent and distinctive running condition, good running level and high employment rate, take preferential steps to develop some Subjects. The cooperation of local and state government is encouraged to form a three-level running system, promoting the development and construction of Subjects, to set up standards for teaching.

According to the Zhuhai City and the Pearl River Delta industrial adjustment and upgrading of development, the school timely adjusts its professional personnel training targeting; develops the regional pillar industries and emerging industries, focus on building stronger software technology, e-commerce, product design, the five key professional and professional group of auto shaping and application of electronic technology to form a brand characteristics; Based on the needs of developing new industry, sets up three or more new subjects. To further improve"School Adjustment and Optimization of the Professional Structure of the Guidance", the school establishes school-enterprise cooperation leading group, the adjustment and optimization of dynamic management mechanism of the professional setting, development of research activities undertaken each year, a local economic and social industry each year to carry out a professional setting targeting research activities, system and personnel training; the establishment of new professional development to meet the demand for local economic construction and the construction of reward system; strengthen the focus on building a professional resource allocation; the establishment of professional construction and development funds.

\section{The core of the New Training Mode}

The core of improving teaching quality is Curriculum and teaching system construction and reform, which is the focus and difficulty of teaching reform. The design of talent training program should be based on technology and occupation post (Group) requirements, refer to the relevant occupation qualification standards, curriculum system and textbook system, post occupation qualification and skills required should be fused into the teaching material and teaching process.

The school has established a curriculum system and teaching materials development, school-enterprise cooperation and construction leading group; a system of school-enterprise cooperation programs, materials development and construction of the Development Fund; has hired influential technical experts and craftsmen in industries and enterprises involved in the curriculum system and the construction of teaching materials; schools and enterprises to participate in the course evaluation system and high-quality materials and reward system. On this basis, to build employment-oriented, quality education based on modern vocational education as the core embodiment of the concept of capacity-building, in line with the school-enterprise cooperation in personnel training mode requires that the curriculum system. At present, the school has started construction of school-enterprise joint development of major courses of 60, 50 in university network courses, will build a national quality course 3,8 provincial-level quality courses; wrote and published the 40 characteristic teaching material.

In the curriculum development and teaching material compilation, the school implements school-enterprise joint design, introduces the industry enterprise technology standards 
and the international general occupation qualification standards, embedded industry new technology new technology and information technology; use of task driven, the work process oriented programming method of preparation of embedded industry new technology new technology new achievement of major teaching. Strive to become the province and even whole nation reflect the nature of higher vocational education curriculum system and quality requirements of the teaching material.

\section{The new Training Mode}

Practical teaching is an important part of the training of higher vocational education and teaching system, which is an indispensable teaching link in higher vocational education talents training. Practical training base is the implementation of practical teaching and the most basic support and material security. The establishment and effective operation of the training base is the key and bottleneck of NTTMSE personnel training mode and also the important platform for cooperation between school and enterprise.

The construction of production operators, professional teaching, training of actual combat, and social services outside the school as one of the "teaching enterprise", is the school's striving for model-building institutions, and the implementation of the two team building, two training positions together to carry out professional training work the NTTMSE personnel training mode is one of the main tasks.

The school is to create about 50 enterprises inside and outside school teaching, continue to develop professional students internship enterprises base, focus on Zhuhai Science and Technology Limited Company, Golden Hill software corporation and other well-known enterprises, to build high level of enterprise practice base; strengthening the construction of practical training base of other types of school-enterprise cooperation; to build 2 national level demonstrative base, 2 productive training base, 1 provincial school-enterprise integration type demonstration training center for the production, 2 intramural productive training base, 3 enterprise training base, constructed from "teaching enterprise"and other training base. The school has constructed teaching and practical training base, through which to realize three functions: to realize the goal of cultivating professional talents needed for the practice and teaching; to implement the main task of teaching in school "teaching enterprise professional teaching points", established professional goals; to implement the "teaching company" has to do with the school-running system breakthrough significance independent professional school goals, for the completion of high-quality professional teaching Task of providing security conditions.

The difficulty of NTTMSE personnel training mode construction is how to cultivate, develop and consolidate the interests of both sides, and the balance of interests of both sides under the conditions of the talent management system and operational mechanism. Therefore, the school has established the school class"teaching enterprise" and training base management center, has set up and improved school-enterprise cooperation "teaching enterprise" training base management system and operation mechanism; has committed to the system of play oneself advantage resource the contribution to the enterprise; to establish a government-led, enterprise participatory funding base construction funds; establishment of school-enterprise cooperation"teaching enterprise" construction, operation, management incentive system.

\section{The key of the new personnel training mode}

The teaching faculty is the key to achieve the goal of personnel training. Professional teaching team is an important form of organization to carry out the professional building, it will not undertake all of the professional teaching work, but also be responsible for professional personnel training mode and program development and implementation of the improvement of professional teaching resources, professional research and social services aspects of the work which is directly related to the success or failure of the professional building, therefore, the construction of the occupational characteristics of the professional teaching team is vital to deepen the reform of vocational education model, to strengthen the professional characteristics, and to comprehensively improve the teaching quality ${ }^{[3]}$.

Professional teaching team and its quality construction in this school is the key elements in the implementation and realization of the demonstrative colleges and schools construction. The construction of teaching team in higher vocational education focuses on team quality, the rational allocation of part-time structure, as well as the influence on the industry professional featuring a high level of professional leaders established; the difficulty of the teaching team-building is the industry influential professional leaders of the solution and part-time teachers teaching forms; teaching team building; the key is to break the traditional mindset, creating the way of the environment, conditions and construction requirements. The school will build more than 1200 part-time teacher resources data bank, hire 30 eminent industry experts as a professional leader; more than $50 \%$ of the professional courses will be taken by part-time teachers, The ratio of double-teacher will reach more than $90 \%$; will nourish 2 national level teaching teachers, 3 provincial "dual ability" teachers, 2 teacher (experts) Studios, creating 2 two-division structure teaching teams at the national level, and 3 at provincial level.

The school will adjust the concept of human resource management and management mechanism; formulate "school-enterprise training professional teachers and school-enterprise interaction management approach employed professional and technical personnel (teachers)" and a series of system, establish school-enterprise "co-employed and co-training " teaching team's incentives and long-term mechanism; In order to break through innovation and personnel distribution system, the establishment and Implementation of both schools and enterprises ensures that the "double post, double-income" hiring system is applied to part-time teachers and key teachers in the school-enterprise entity positions who undertake over-leaded work; the implementation of the teacher to affiliated enterprises practice system, to participate in production practices, engineering 
combination of research focused on the reform of professional teacher performance evaluation system. The school will break the traditional model of professional teaching in schools, reform the allocation of teaching resources, teaching innovation and professional teaching organization form, lay the basis of the environment and conditions for the construction of the excellent two-division structure of professional teaching team.

\section{The Feedback and Tracking of the New Training Mode}

The quality of education and teaching, the end-result of the various aspects of school personnel training is the goal of the school's work. Teaching Quality Assurance construction is a systematic project, which includes the four aspects of the quality of teaching goals, teaching resources and support, teaching, management and teaching quality monitoring. National demonstration goals of colleges and schools, the teaching quality guarantee must reflect the school-enterprise work closely with the new content and requirements.

The school and the enterprise work together to build quality employment-oriented, covering personnel training process of teaching, culture and the development of a full range of diversification of the whole process of evaluation index system. In the teaching evaluation of construction, the school has set up a combination of traditional examinations, teaching evaluation and appraisal of vocational skills, vocational skills contest, the study process of tracking feedback and other advantages of a variety of assessment methods of teaching quality evaluation index system.

Student employment is the guide of personnel training, so the school will consider students employment of personnel training as an important part of the work, take full advantage of the industry enterprises, cooperation between school and enterprise operation process, the professional talents cultivation and employment of organic unity; graduates employment mechanism innovation, and enterprises to create employment rate, the quality of employment ( counterparts rate, salary and enterprise visibility ), enterprise satisfaction, graduates' employment quality result evaluation index system; build a graduate occupation career development indicator system and the tracking feedback and analysis system. The school has set up an organization led by the government, industries and enterprises to participate in the traction of the employment of Graduates Working Committee; construction of government leading, enterprise to build a high level of employment of talent supply and demand information sharing platform; establishing school-enterprise cooperation employment index system, establish school-enterprise cooperation employment system and incentives, forms the enterprise receives and recommended graduate employment long-term incentive mechanism.

In addition, school-enterprise cooperation also extends to the social service system and school-enterprise win-win cooperation development.

The school strives to carry out technical services, technical training and continuing education of the social service system for enterprises, establishes a cross-department, interdisciplinary professional school-enterprise joint technology development, technical services team; school professional advantage to set up regional economy technology service center; and the industry enterprises to set up a high level industry occupation skill training institutions; give full play to the school resources advantages of radiation, to further strengthen cooperation with counterparts in colleges and universities, perfect the system of regular exchange. In order to build systematic mechanism innovation significance of the "Independent College", all-around advance resource sharing, mutual benefit and win-win of deep-cooperation; to continue to carry out higher separate entrance examination system reform pilot job, exploration of "knowledge plus skill", high school level exam plus occupation aptitude tests such as the diversification of enrollment mechanism; enterprise, by training, orientation training and other means, for enterprise employees together the school carries out pilot job in adult education specialist qualifications enrollment reform, strive to improve social services and the training of talents, security cooperation between school and enterprise sustainable development.

The NTTMSE personnel training mode of the work has been in full swing, and the school has completed nearly $50 \%$ of the target. Practice has proved that the NTTMSE talents training mode and the application of safeguard measures has promoted the school personnel training quality of college students, During a recent period of three years the students has obtained 210 items of various awards, 86 of which are national-level contest award, and a gold medal, such as the national first prize the first China (Shenzhen) international occupation education exhibition "invention" cup competition gold medal, "Zhangjiang Cup" industrial design / Visual Design Competition Gold Award, students of industrial design work by Vice Premier of the State Council, the provincial Party Secretary Zhangdejiang Guangdong, the then governor Comrade Huanghuahua's inscription. The school personnel training has improved the quality of access to social recognition, in recent years, each year nearly 8000 people of the freshmen, a proportion of $98 \%$ volunteers, were recruited from first admission. Graduates are quite welcomed to employers, annual graduates overall employment rate maintains in $97.5 \%$ above. The NTTMSE personnel training mode for the successful implementation of the area of the other inside higher vocational colleges produced apparent radiation, and has made a great contribution to the regional economic and social development, the students, schools, and enterprises can benefit from extensive, realizing multi-win-win situation, common development.

\section{References}

[1] Wang Xueqing, Yin Mei. Research into School-Enterprise Talent Training model in Higher Vocational Education. Journal of Lianyungang Technical College, 2011,9: 74-77.

[2] Zhang Linna, Zhou Qi, Zang Shujun."3+1" School-Enterprise Cooperation in Personnel Training Mode is the New Way of Reform for College Personnel Training Mode. Science and Technology Innovation Herald, 2010,6:199.

[3] Jiang Yingli, Wang Jinsong. The Research of Occupation Specialty Teaching Team Construction. Traffic Occupation Education, 2010,1: 4-6. 